\title{
Deletions of pfhrp2 and pfhrp3 genes of Plasmodium falciparum from Honduras, Guatemala and Nicaragua
}

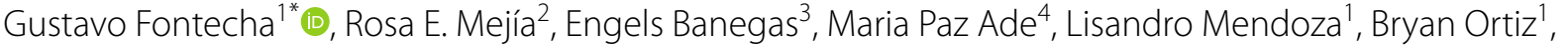 \\ Isaac Sabillón', Gerardo Alvarado', Gabriela Matamoros ${ }^{1}$ and Alejandra Pinto ${ }^{1}$
}

\begin{abstract}
Background: Malaria remains a public health problem in some countries of Central America. Rapid diagnostic tests (RDTs) are one of the most useful tools to assist in the diagnosis of malaria in remote areas. Since its introduction, a wide variety of RDTs have been developed for the detection of different parasite antigens. PfHRP2 is the most targeted antigen for the detection of Plasmodium falciparum infections. Genetic mutations and gene deletions are important factors influencing or affecting the performance of rapid diagnostic tests.

Methods: In order to demonstrate the presence or absence of the pfhrp2 and pfhrp3 genes and their flanking regions, a total of 128 blood samples from patients with P. falciparum infection from three Central American countries were analysed through nested or semi-nested PCR approaches.

Results: In total, 25.8 and 91.4\% of the isolates lacked the region located between exon 1 and exon 2 of pfhrp2 and pfhrp3 genes, respectively. Parasites from the three countries showed deletions of one or both genes. The highest proportion of pfhrp2 deletions was found in Nicaragua while the isolates from Guatemala revealed the lowest number of pfhrp2 deletions. Parasites collected from Honduras showed the highest proportion of phfrp3 absence (96.2\%). Twenty-one percent of isolates were double negative mutants for the exon 1-2 segment of both genes, and $6.3 \%$ of isolates lacked the full-length coding region of both genes.

Conclusions: This study provides molecular evidence of the existence of $P$. falciparum isolates lacking the pfhrp 2 and pfhrp3 genes, and their flanking regions, in Honduras, Guatemala and Nicaragua. This finding could hinder progress in the control and elimination of malaria in Central America. Continuous evaluation of RDTs and molecular surveillance would be recommended.
\end{abstract}

Keywords: Malaria, Central America, Plasmodium falciparum, RDT, pfhrp2, pfhrp3

\section{Background}

Malaria remains a public health problem for most tropical countries. However, there are notable differences in the incidence of malaria between geographic regions. Within the Central American sub region, two countries (Costa Rica and El Salvador) reported fewer than 15 indigenous malaria cases in 2016, and, according to the

\footnotetext{
*Correspondence: gustavo.fontecha@unah.edu.hn

${ }^{1}$ Microbiology Research Institute, Universidad Nacional Autonoma de Honduras, Tegucigalpa, Honduras

Full list of author information is available at the end of the article
}

World Health Organization, are projected to eliminate malaria by 2020 . In Nicaragua, Guatemala and Honduras however, a total of 15,476 cases were reported in 2016, representing the largest burden in Central America. Although the prevalence of malaria is decreasing in this region, Panama and Nicaragua showed an increase in case incidence between 2010 and 2016. Approximately, $90 \%$ of malaria cases in Nicaragua and Honduras are due to Plasmodium vivax, and the remaining $10 \%$ to Plasmodium falciparum. Guatemala, on the other hand, has been reporting fewer than 10 cases of falciparum malaria in recent years [1]. 
As this sub-region of the Americas approaches the goal of eliminating malaria by the year 2030 [2], it is necessary to include more intensive strategies of prevention, timely diagnosis and treatment of infections, especially in areas with low social development, where appropriate health infrastructure is not available. Rapid diagnostic tests (RDTs) based on immunochromatography are one of the most useful tools to assist in the diagnosis of malaria in the absence of good quality microscopy services. Since their introduction, a wide variety of RDTs have been developed for the detection of different parasite antigens [3]. Two antigens (e.g. aldolase, pLDH) are produced by all Plasmodium species (pan-specific tests), but the PfHRP2 antigen (Histidine-Rich Protein-2) is produced only by $P$. falciparum. PfHRP2 is an abundant and heat stable antigen, which makes it a highly sensitive target for the diagnosis of falciparum malaria $[3,4]$.

PfHRP2 is a non-essential protein encoded by pfhrp 2 gene, located on chromosome 8 of $P$. falciparum, and pfhrp3 is an structural homologue of pfhrp2 [5], which is located on chromosome 13. Both antigens crossreact when detected by some PfHRP2-based RDTs [6]. A retrospective study carried out with 128 samples collected in Iquitos reported that 41 and $70 \%$ lacked the $p f h r p 2$ or $p f h r p 3$ genes, respectively, and $21.6 \%$ of parasites lacked both genes [7]. Such findings represent an emerging challenge for the diagnosis and control of malaria, especially since several worldwide studies report parasite isolates that present double deletions for these genes [8-14]. All this information has been conveniently summarized by WHO in a website [15] that allows to perceive graphically the spread of parasite isolates for which the PfHRP2-based RDTs could no longer be effective. For this reason, WHO has prioritized efforts to address the problem posed by parasites with these deletions [16, 17], and proposes that the analysis of archival samples could be useful to determine the existence and geographic distribution of the double-negative populations of the parasite [16].

The only study published on this topic in Central America dates from 2015, in which samples from Honduras collected between 2008 and 2009 were analysed through a molecular approach [18]. These authors do not report isolates with double-deletions but found a high proportion of $p$ fhrp3-negative parasites and suggested that PfHRP2-based RDTs could continue to be used in Honduras, but at the same time they propose further studies including samples from a wider geographical area. Thus, this study aims to be an update of the topic for the Central American sub-region, analysing populations of the parasite from Guatemala, Nicaragua and Honduras.

\section{Methods}

The aim of the study was to evaluate the presence of the pfhrp 2 and pfhrp3 genes and their flanking regions in 128 falciparum malaria samples from Central America, previously diagnosed by microscopy. Twenty-one samples were collected from Guatemala and 55 samples from Nicaragua, during 2015, and 52 samples from Honduras were collected during $2011(\mathrm{n}=10), 2012(\mathrm{n}=11)$ and $2017(n=31)$. Samples from Guatemala were collected from the department of Escuintla. In Nicaragua the samples came from the North Atlantic Autonomous Region (RAAN), while in Honduras the majority of samples came from the department of Gracias a Dios and less than $10 \%$ were obtained from five other departments (Colón, Atlántida, Cortés and Islas de la Bahía) (Fig. 1). The samples were collected for routine diagnosis and malaria surveillance in the three countries in different endemic localities. The criteria for the selection of samples was by convenience. The Ministries of Health of each country selected a random percentage of positive samples for their analysis. Patients' informed consent was requested for diagnostic procedures. After confirming the diagnosis of falciparum malaria by microscopic observation of the parasite, a blood sample was collected on Whatman $^{\text {TM }}$ filter paper (GE Healthcare Bio-Sciences Corp, NJ, USA) for routine chloroquine resistance surveillance through a molecular approach $[19,20]$. Parasite densities were determined for most samples. Samples with less than 10 parasites/100 white blood cells (WBC) were considered as low density. A moderate density parasitaemia included samples with $10-50$ parasites/100 WBC. Samples with more than 50 parasites/100 WBC were considered as high density parasitaemia.

Those blood samples were used for the analysis of pfhrp 2 and pfhrp3 deletions. DNA was extracted using a Chelex-100 based method [21]. In order to assess the quality of the extracted DNA, a region of the human beta-globin gene was amplified by conventional PCR [22]. The microscopic diagnosis of the parasite species was confirmed through a species-specific PCR approach using the primers AL7178/AL7142 and AL7175/AL7074 according to previous reports $[23,24]$. The amplification of parasite sequences was indicative of a good-quality DNA that would allow the detection of target sequences for the genes $p f h r p 2$, pfhrp 3 and flanking sequences. In order to rule out the possibility of false negative results attributable to poor DNA quality or insufficient amounts of the parasite's genome, the amplification of the single copy gene $p f m s p 1$ in those samples showing a double deletion in partial sequences of $p f h r p 2$ and $p f h r p 3$ genes was performed. The amplification procedures were carried out through a nested PCR according to previous reports $[25,26]$. 


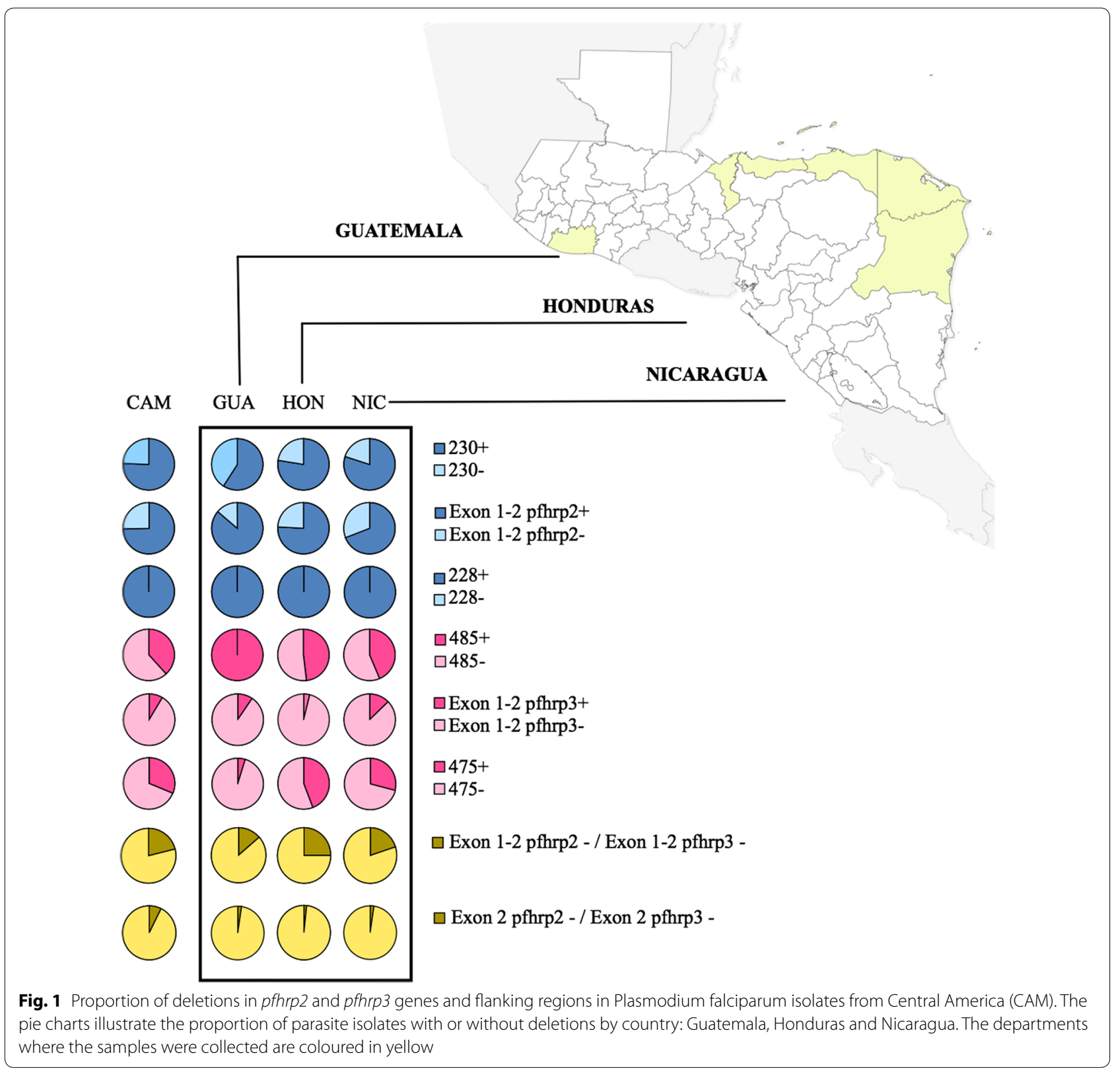

In order to detect the presence or absence of a partial coding region between exons 1 and 2 of the genes pfhrp 2 and $p f h r p 3$, and the flanking regions upstream and downstream of each gene, 6 nested or semi-nested PCR reactions were performed as outlined in Fig. 2 [18]. Primers' list, sequences, annealing temperatures, and amplicon sizes are detailed in Table 1. Briefly, each reaction was carried out in a volume of $25 \mu$ l composed of $12.5 \mu \mathrm{l}$ of $2 \mathrm{X}$ Master mix (Promega Corp.), $1.0 \mu \mathrm{l}$ of each primer at a concentration of $10 \mu \mathrm{M}$ and $2.0 \mu \mathrm{l}$ of genomic DNA. Reactions of both the primary and nested PCR were carried out by an initial denaturation temperature at $95^{\circ} \mathrm{C}$ for $5 \mathrm{~min}$, followed by 35 cycles of $95^{\circ} \mathrm{C}$ for $1 \mathrm{~min}$, an annealing step for $1 \mathrm{~min}, 72{ }^{\circ} \mathrm{C}$ for $1 \mathrm{~min}$; and a final extension step at $72{ }^{\circ} \mathrm{C}$ for $5 \mathrm{~min}$. A second PCR was performed after each initial reaction, including $1 \mu \mathrm{l}$ of the first PCR product. Two positive and negative controls were used within each experiment. All negative results were amplified a second time. If a positive result was obtained, it was considered positive. The coding regions of those samples with double deletions (pfhrp2 and pfhrp3 negative) were amplified a third time.

To confirm the complete lack of the pfhrp 2 and $p f h r p 3$ genes, all samples that did not amplify the exon $1-2$ 

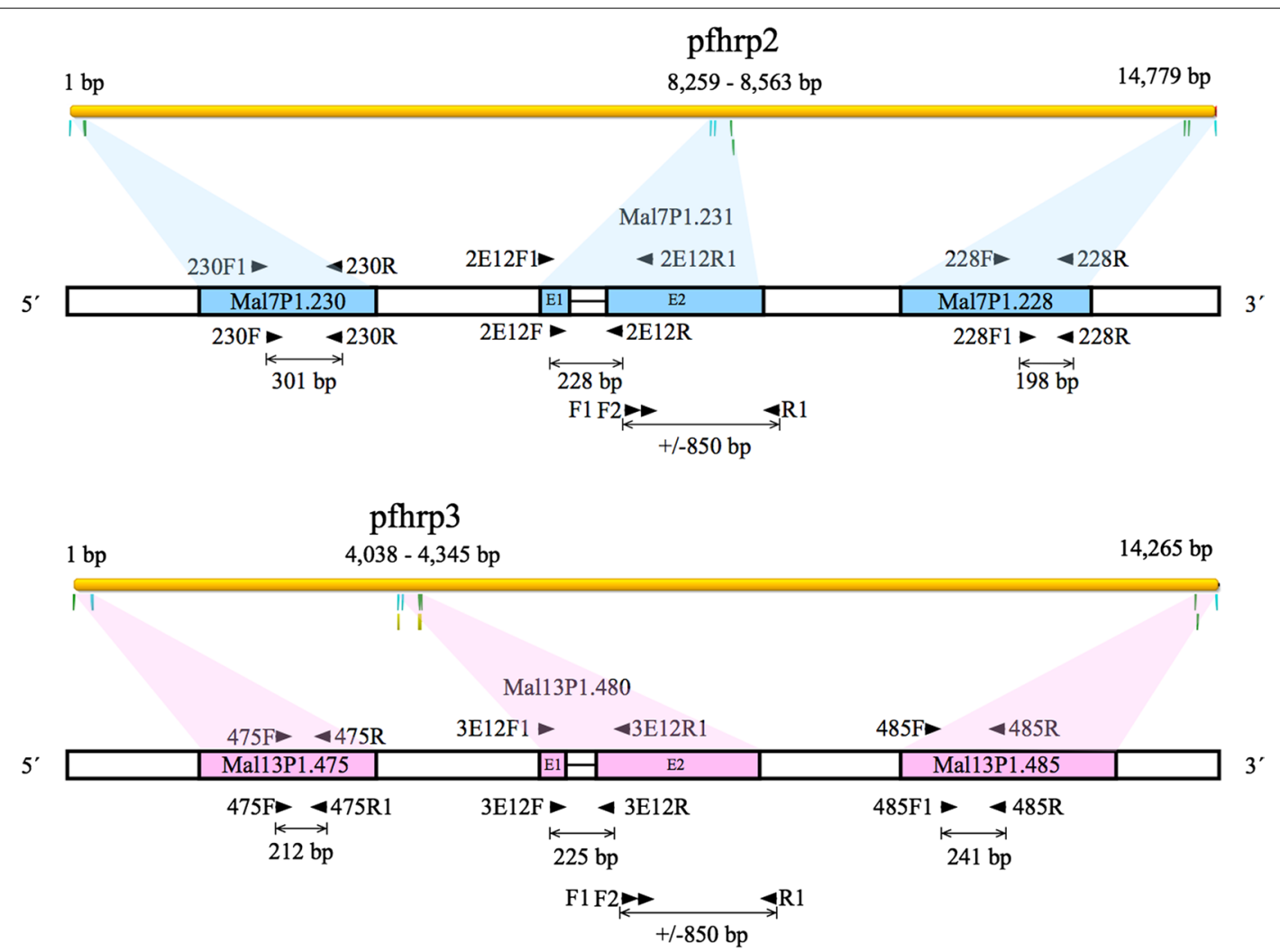

Fig. 2 Scheme of the pfhrp2 and pfhrp3 genes and their flanking sequences. The black arrows indicate the names and targets of the primers used to amplify each region, as well as the size of the amplicons. The parasite strain used for the in silico analysis was 3D7 (GenBank Accession Number: AL844507.3)

segment of both genes were amplified by a semi-nested PCR targeting the exon 2 . Both reactions were carried out in a $50 \mu \mathrm{l}$ volume and included $25 \mu \mathrm{l}$ of $2 \times$ Master mix (Promega Corp.), $2.0 \mu \mathrm{l}$ of each $10 \mu \mathrm{M}$ primer (F1/ $\mathrm{R} 1$ in the first round and F2/R1 in the second round), and $1.0 \mu \mathrm{l}$ of DNA. Reactions were carried out by an initial denaturation temperature at $94{ }^{\circ} \mathrm{C}$ for $10 \mathrm{~min}$, followed by 35 and 37 cycles respectively of $94{ }^{\circ} \mathrm{C}$ for $50 \mathrm{~s}$, an annealing step for $50 \mathrm{~s}, 72{ }^{\circ} \mathrm{C}$ for $1 \mathrm{~min}$, and a final extension step at $72{ }^{\circ} \mathrm{C}$ for $10 \mathrm{~min}$ (Table 1). The expected PCR product ranged between 600 and $950 \mathrm{bp}$.

\section{Results}

A total of 128 blood samples from patients with $P$. falciparum infection were diagnosed by microscopy in three Central American countries, which is the gold standard method for malaria. All the samples were confirmed to be falciparum infections through a molecular approach. $50.6 \%$ of the samples showed high parasitic density, $27.8 \%$ were moderate and $21.5 \%$ were low. Samples from the three countries showed heterogeneous parasitic density with no correlation between geographical origin and parasitic density. Coding regions of the pfhrp 2 and $p f h r p 3$ genes and the corresponding upstream and downstream flanking regions were amplified by nested PCR. Overall, $25.8 \%$ of the isolates were negative for the partial coding region between exon 1-2 (intron 1) of pfhrp 2 and $91.4 \%$ of the isolates lacked the homologous region of pfhrp3 (Table 2). Parasites from the three countries showed deletions of one or both gene regions. The highest proportion of exon 1-2 pfhrp 2 deletions was found in Nicaragua (30.9\%) while the isolates from Guatemala revealed the lowest number of deletions (14.3\%). Parasites collected from Honduras showed the highest proportion of exon 1-2 phfrp3 deletion (96.2\%).

A relevant result was the finding of $27(21 \%)$ double negative isolates ( $p f h r p 2$ negative and $p f h r p 3$ negative). Most of those double negative parasites were detected in Honduras 13/52 (25\%), followed by Nicaragua 11/55 (20\%) and Guatemala 3/21 (14.3\%). No significant differences were found in the frequency of the deletions between the three different years of collection in Honduras. The pfmsp-1 gene was successfully amplified in the 27 double negative isolates, showing a distribution of $52 \%$ for the K1 genotype and 48\% for MAD20. 
Table 1 Primer sequences and amplification conditions of pfhrp2 and pfhrp3 genes, and their respective flanking sequences

\begin{tabular}{|c|c|c|c|c|c|}
\hline Target sequence & Reaction & Primer & Primer sequence & $\begin{array}{l}\text { Annealing } \\
\text { temp }\left({ }^{\circ} \mathrm{C}\right)\end{array}$ & Amplicon size (bp) \\
\hline \multirow{4}{*}{$\begin{array}{l}\text { pfhrp2 UPSTREAM PF3D7_0831900, } \\
\text { (MAL7P1.230) }\end{array}$} & \multirow[t]{2}{*}{ Primary } & $230 \mathrm{~F} 1$ & 5'GATATCATTAGAAAACAAGAGCTTAG3' & \multirow[t]{2}{*}{63} & \multirow[t]{4}{*}{301} \\
\hline & & $230 R$ & 5'TATCCAATCCTTCCTTTGCAACACC $3^{\prime}$ & & \\
\hline & \multirow[t]{2}{*}{ Semi-nested } & $230 \mathrm{~F}$ & 5'TATGAACGCAATTTAAGTGAGGCAG3' & \multirow[t]{2}{*}{65} & \\
\hline & & $230 \mathrm{R}$ & 5'TATCCAATCCTTCCTTTGCAACACC $3^{\prime}$ & & \\
\hline \multirow[t]{4}{*}{ pfhrp2 Exon 1-2,PF3D7_0831800 } & \multirow[t]{2}{*}{ Primary } & $2 \mathrm{E} 12 \mathrm{~F} 1$ & 5'GGTTTCCTTCTCAAAAAATAAAG3' & \multirow[t]{2}{*}{55} & \multirow[t]{4}{*}{228} \\
\hline & & 2E12R1 & 5'TCTACATGTGCTTGAGTTTCG3' & & \\
\hline & \multirow[t]{2}{*}{ Nested } & $2 \mathrm{E} 12 \mathrm{~F}$ & 5'GTATTATCCGCTGCCGTTTTTTGCC3' & \multirow[t]{2}{*}{62} & \\
\hline & & $2 \mathrm{E} 12 \mathrm{R}$ & 5'CTACACAAGTTATTATTAAATGCGGAA3' & & \\
\hline \multirow{4}{*}{$\begin{array}{l}\text { pfhrp2 DOWNSTREAM PF3D7_0831700, } \\
\text { (MAL7P1.228) }\end{array}$} & \multirow[t]{2}{*}{ Primary } & $228 \mathrm{~F}$ & 5'AGACAAGCTACCAAAGATGCAGGTG3' & \multirow[t]{2}{*}{60} & \multirow[t]{4}{*}{198} \\
\hline & & $228 \mathrm{R}$ & 5'TAAATGTGTATCTCCTGAGGTAGC3' & & \\
\hline & \multirow[t]{2}{*}{ Semi-nested } & $228 \mathrm{~F} 1$ & 5'CCATTGCTGGTTTAAATGTTTTAAG3' & \multirow[t]{2}{*}{63} & \\
\hline & & $228 \mathrm{R}$ & 5'TAAATGTGTATCTCCTGAGGTAGC3' & & \\
\hline \multirow{4}{*}{$\begin{array}{l}\text { pfhrp3 DOWNSTREAM PF3D7_1372100, } \\
\text { (MAL13P1.485) }\end{array}$} & \multirow[t]{2}{*}{ Primary } & $485 \mathrm{~F}$ & 5'TTGAGTGCAATGATGAGTGGAG3' & \multirow[t]{2}{*}{60} & \multirow[t]{4}{*}{241} \\
\hline & & $485 R$ & 5'AAATCATTTCCTTTTACACTAGTGC3' & & \\
\hline & \multirow[t]{2}{*}{ Semi-nested } & $485 F 1$ & 5'GTTACTACATTAGTGATGCATTC3' & \multirow[t]{2}{*}{59} & \\
\hline & & $485 R$ & 5'AAATCATTTCCTTTTACACTAGTGC3' & & \\
\hline \multirow[t]{4}{*}{ pfhrp3 Exon 1-2, PF3D7_1372200 } & \multirow[t]{2}{*}{ Primary } & $3 \mathrm{E} 12 \mathrm{~F} 1$ & 5'GGTTTCCTTCTCAAAAAATAAAA3' & \multirow[t]{2}{*}{53} & \multirow[t]{4}{*}{225} \\
\hline & & 3E12R1 & 5'CCTGCATGTGCTTGACTTTA3' & & \\
\hline & \multirow[t]{2}{*}{ Nested } & $3 \mathrm{E} 12 \mathrm{~F}$ & 5'ATATTATCGCTGCCGTTTTTGGCT3' & \multirow[t]{2}{*}{62} & \\
\hline & & $3 \mathrm{E} 12 \mathrm{R}$ & 5'CTAAACAAGTTATTGTTAAATTCGGAG3' & & \\
\hline pfhrp3 UPSTREAM PF3D7_1372400, & Primary & $475 \mathrm{~F}$ & 5'TTCATGAGTAGATGTCCTAGGAG3' & 55 & 212 \\
\hline L13P1.475) & & $475 R$ & 5'TCGTACAATTCATCATACTCACC $3^{\prime}$ & & \\
\hline & Semi-nested & $475 F$ & 5'TTCATGAGTAGATGTCCTAGGAG3' & 61 & \\
\hline & & $475 \mathrm{R} 1$ & 5'GGATGTTTCGACATTTTCGTCG3' & & \\
\hline pfhrp2 Exon 2 & Primary & Pfhrp2F1 & 5'CAAAAGGACTTAATTTAAATAAGAG3' & 55 & $600-950$ \\
\hline & & Pfhrp2R1 & 5'AATAAATTTAATGGCGTAGGCA3' & & \\
\hline & Semi-nested & Pfhrp2F2 & 5'ATTATTACACGAAACTCAAGCAC3' & 55 & \\
\hline & & Pfhrp2R1 & 5'AATAAATTTAATGGCGTAGGCA3' & & \\
\hline pfhrp3 Exon 2 & Primary & Pfhrp3F1 & 5'AATGCAAAAGGACTTAATTC3' & 55 & $600-950$ \\
\hline & & Pfhrp3R1 & 5'TGGTGTAAGTGATGCGTAGT3' & & \\
\hline & Semi-nested & Pfhrp3F2 & 5'AAATAAGAGATTATTACACGAAAG3' & 55 & \\
\hline & & Pfhrp3R1 & 5'TGGTGTAAGTGATGCGTAGT3' & & \\
\hline
\end{tabular}

Table 2 Number and percentages of samples showing deletions of the pfhrp2 and pfhrp3 partial sequences (exon 1-2) by country and year of collection

\begin{tabular}{llllllc}
\hline Country & $\begin{array}{l}\text { Year } \\
\text { of collection }\end{array}$ & Exon 1-2 pfhrp2+ & Exon 1-2 pfhrp2- & Exon 1-2 pfhrp3+ & Exon 1-2 pfhrp3- & Total \\
\hline Guatemala & 2015 & $18(85.7 \%)$ & $3(14.3 \%)$ & $2(9.5 \%)$ & $19(90.5 \%)$ & $21(16.4 \%)$ \\
Nicaragua & 2015 & $38(69.1 \%)$ & $17(30.9 \%)$ & $7(12.7 \%)$ & $48(87.3 \%)$ & $55(43 \%)$ \\
Honduras & 2011 & $6(60 \%)$ & $4(40 \%)$ & - & $10(100 \%)$ & $10(7.8 \%)$ \\
Honduras & 2012 & $11(100 \%)$ & - & - & $9(81.8 \%)$ & $11(8.6 \%)$ \\
Honduras & 2017 & $22(71 \%)$ & $9(29 \%)$ & $11(8.6 \%)$ & $117(91.4 \%)$ & $31(24.2 \%)$ \\
& Total & $95(74.2 \%)$ & $33(25.8 \%)$ & $128(100 \%)$ \\
\hline
\end{tabular}


Nested PCRs were also carried out to amplify the flanking regions of pfhrp2 (MAL7P1.230 and MAL7P1.228), and pfhrp3 (MAL13P1.485 and MAL13P1.475). Most of the isolates $(75.8 \%)$ revealed the presence of the MAL7P1.230 region, and almost all the isolates (99.2\%) successfully amplified the MAL7P1.228 region. On the other hand, more than $62 \%$ of isolates seem to have deleted the MAL13P1.485 and MAL13P1.475 regions (Table 3, Fig. 2). When comparing the 6 markers, the most frequently deleted locus was pfhrp3 (91.4\%), followed by MAL13P1.475 (68.8\%). All samples amplified properly at least one of the 6 analysed loci, which indicates that the quality and quantity of DNA was sufficient to guarantee reliability in the negative results.

Five deletion patterns were recorded when analysing the exon 1-2 pfhrp2 sequence plus the flanking regions, while the loci associated to pfhrp 3 revealed 6 different deletion patterns (Table 3). Most of the samples (58.6\%) did not reveal any deletion in the analysed region of the chromosome 8 , however $<5 \%$ of the samples seem to keep the region of the chromosome 13 intact without deletions. None of the isolates showed a complete lack of the exon 1-2 region of pfhrp2 gene and both flanking genes, while many samples $(48.4 \%)$ seem to have deleted the entire pfhrp 3 region.

In order to confirm the deletion of the pfhrp 2 and pfhrp3 genes, the full length of exon 2 was amplified [27] in those samples that showed a double deletion of the sequence between exon 1 and exon 2. As shown in Table 4, 8 of 27 isolates revealed total absence of the two exons in both genes. The rest of the isolates amplified at least one exon 2 of either of both genes. Isolates with complete deletions of both genes were detected in all three countries.

\section{Discussion}

This is the first report of deletions of the genes pfhrp2, pfhrp3 and their neighbouring regions in $P$. falciparum parasites collected from Guatemala and Nicaragua, and this is also the second report that includes samples

Table 3 Number and percentages of samples showing deletions of the pfhrp2 and pfhrp3 genes and their flanking regions by country

\begin{tabular}{|c|c|c|c|c|c|c|}
\hline MAL7P1.230 & $\begin{array}{l}\text { pfhrp2 Exon } \\
1-2\end{array}$ & MAL7P1.228 & Guatemala, n (\%) & Nicaragua, n (\%) & Honduras, n (\%) & Total, n (\%) \\
\hline+ & + & + & $12(57.1)$ & $30(54.5)$ & $33(63.5)$ & $75(58.6)$ \\
\hline- & + & + & $6(28.6)$ & $8(14.5)$ & $6(11.5)$ & $20(15.6)$ \\
\hline+ & - & + & - & $14(25.4)$ & $7(13.5)$ & $21(16.4)$ \\
\hline- & - & + & $3(14.3)$ & $3(5.5)$ & $5(9.6)$ & $11(8.6)$ \\
\hline \multirow[t]{2}{*}{+} & - & - & - & - & $1(1.9)$ & $1(0.8)$ \\
\hline & & Total & $21(100)$ & $55(100)$ & $52(100)$ & 128 \\
\hline MAL13P1.485 & $\begin{array}{l}\text { pfhrp3 Exon } \\
1-2\end{array}$ & MAL13P1.475 & Guatemala, n (\%) & Nicaragua, n (\%) & Honduras, n (\%) & Total, n (\%) \\
\hline- & - & - & $18(85.7)$ & $21(38.2)$ & $23(44.2)$ & $62(48.4)$ \\
\hline+ & - & - & - & $15(27.3)$ & $6(11.5)$ & $21(16.4)$ \\
\hline+ & - & + & - & $5(9.1)$ & $17(32.7)$ & $22(17.2)$ \\
\hline- & - & + & $1(4.8)$ & $7(12.7)$ & $4(7.7)$ & $12(9.4)$ \\
\hline+ & + & + & - & $4(7.3)$ & $2(3.8)$ & $6(4.7)$ \\
\hline \multirow[t]{2}{*}{-} & + & - & $2(9.5)$ & $3(5.4)$ & - & $5(3.9)$ \\
\hline & & Total & $21(100)$ & $55(100)$ & $52(100)$ & 128 \\
\hline
\end{tabular}

Table 4 Number and percentages of samples showing deletions of pfhrp2 and pfhrp3 sequences (exon 1-2 and exon 2) by country

\begin{tabular}{|c|c|c|c|c|c|c|c|}
\hline $\begin{array}{l}\text { Exon 1-2 } \\
\text { pfhrp2 }\end{array}$ & Exon 2 pfhrp 2 & $\begin{array}{l}\text { Exon 1-2 } \\
\text { pfhrp3 }\end{array}$ & Exon 2 pfhrp3 & Guatemala, n (\%) & Nicaragua, n (\%) & Honduras, n (\%) & Total, n (\%) \\
\hline- & - & - & - & $3(11.1)$ & $2(7.4)$ & $3(11.1)$ & $8(29.6)$ \\
\hline- & - & - & + & 0 & $1(3.7)$ & $1(3.7)$ & $2(7.4)$ \\
\hline- & + & - & + & 0 & $6(22.2)$ & $6(22.2)$ & $12(44.4)$ \\
\hline \multirow[t]{2}{*}{-} & + & - & + & 0 & $2(7.4)$ & $3(11.1)$ & $5(18.5)$ \\
\hline & & & & $3(11.1)$ & $11(40.7)$ & $13(48.1)$ & $27(100)$ \\
\hline
\end{tabular}


collected from Honduras [18]. Motivated by the growing number of similar reports in South America [7-10, 28-30], Asia [11, 12, 31] and Africa [14, 32-36], this study analysed the presence or absence of 6 loci located on chromosomes 8 and 13 of the parasite using archived specimens from Central America [16] with the aim of estimating the frequency of deletions around the genes pfhrp 2 and $p f h r p 3$.

Although RDTs are a valuable tool to establish the diagnosis of falciparum malaria, especially in areas where routine microscopic diagnosis is not available, these tests could yield false negative results due to undetectable concentrations of the PfHRP2 antigen in low parasitaemias [37], to the absence of expression of this protein when the parasite has deleted some genomic segments [16] or other causes listed by WHO [17] that should be investigated in each region or country. The main consequence of the deletions of $p f h r p 2$ and $p f h r p 3$ genes is the impossibility of establishing an adequate diagnosis of malaria, especially where it is solely based on RDTs that exclusively detect the PfHRP2 protein [7, 38, 39].

Amplification of coding sequences and their flanking regions through a nested-PCR approach is a commonly used method to investigate deletions of $p f h r p 2$ and $p f h r p 3$ $[18,27,38,40]$. Due to the challenge of guaranteeing the absence of a genetic sequence based only on a negative amplification result, some experiments were conducted to achieve the greatest certainty possible. Each negative experiment was repeated up to 3 times. In addition, the single copy gene $p f m s p-1$ was successfully amplified for the samples that yielded a negative result for both gene regions. The results obtained suggest that the absence of amplification does not seem to be due to a low DNA concentration of the parasite, since it was not possible to establish any association between samples with low, moderate or high parasitaemia and absence of amplification for any loci. Also, given that all samples amplified at least one of the 6 analysed loci, these results seem to be reliable and allow to confirm the existence of deletions of the sequences associated with the genes $p f h r p 2$, pfhrp3 and their flanking regions in the natural populations of $P$. falciparum circulating in Central America.

Before this study, there was not enough information of deletions in the $p f h r p 2$ and $p f h r p 3$ genes in parasites from Central America [15]. The only study available analysed 68 samples collected between 2008 and 2009, in Puerto Lempira city in the Honduran Moskitia [18]. Those authors found that all samples were positive for pfhrp 2 and its flanking sequences, and therefore PfHRP2based RDTs could be considered useful in this geographic region at the time. Interestingly, in this study 10 archival samples collected 2 years later (2011) in Honduras showed $40 \%$ of isolates with deletion in the $p f h r p 2$ gene.
This could be attributed both to the selective adaptation of the parasite in a short period of time, and to the fact that the samples were collected in some regions of the country that were not represented in the previous study (Colon, Roatan and Gracias a Dios). Abdallah et al. [18] also reported $44 \%$ of parasites lacking the $p f h r p 3$ region and suggested the need to expand the research with samples collected from other geographic regions and for a longer time span. Following that recommendation, and according to the results obtained in this study, the proportion of parasites lacking $p f h r p 3$ in this study area was higher than that previously reported in Puerto Lempira. This high percentage of pfhrp3-negative parasites is in agreement with the large genomic deletions in the chromosome 13 described in the reference line HB3, a parasite isolate collected from Honduras [41].

When analysing all the samples collected from the three Central American countries, $75 \%$ of the isolates amplified successfully the $p f h r p 2$ gene, while only $9 \%$ of the isolates were $p f h r p 3$-positive. A WHO web mapping tool that tracks 3 of the major biological threats to malaria control and elimination compiled 53 surveys from 7 South American countries regarding pfhrp $2 / p f h r p 3$ deletions [42]. Despite the heterogeneity of all these surveys, there is a general trend indicating that deletions in the pfhrp2 gene are less frequent than those in the pfhrp 3 gene; which is consistent with the current results. These coincidences could be attributed to similar characteristics in the evolution of the parasites from South and Central America. The high percentage of deletions in the pfhrp3 gene that are observed in some localities of Colombia [8] and Peru [7] is also of special interest.

Regarding the flanking sequences of the pfhrp 2/ $p f h r p 3$ genes, all isolates retained the downstream locus MAL7P1.228, in a similar way to that reported in Eritrea $[38,40]$, where the MAL13P1.475 region was also the most frequently deleted locus. When comparing the results of this study with those reported previously [18], it is noteworthy that the 4 flanking regions, both of $p f h r p 2$ and pfhrp3 now reveal a high number of deletions, which would support the hypothesis of the rapid appearance of deletions in these genetic regions. Nevertheless, one of the most interesting results of this study is the finding of $26(20.3 \%)$ isolates with a double deletion (pfhrp2/pfhrp3 negative for exon 1-2). Some authors have stated that the deletion of those particular genetic sequences is the result of multiple independent events instead of the dispersion of strains originated from a single event $[43,44]$. However, once they emerge, the rapid spread of doublenegative populations could be caused by the selection of these parasites by the pressure acting on these variants [45], as demonstrated also by stochastic simulation when the use of RDTs is based on the exclusive detection 
of the PfHRP2 antigen [46]. Despite the reason behind the emergence and spread of this genotypes in Central America, the presence of double-negative parasites in this endemic region has direct implications on the use of RDTs for routine diagnosis, especially in areas where microscopy is not feasible. This new finding could pose a threat to national malaria programmes, mainly due to the risk for patients infected with these parasites not receiving a timely and correct diagnosis and treatment; as well, non-PfHRP2-based RDTs have demonstrated limited sensitivity and heat instability [16].

In the three countries analysed in this study, the Ministries of Health use RDTs based on detection of the PfHRP2 antigen: CareStart ${ }^{\mathrm{TM}}$ Malaria HRP2/pLDH(Pf/ Pv) Combo (Honduras), SD Bioline MALARIA Ag P.f/ P.v (Nicaragua) and CareStart ${ }^{\mathrm{TM}}$ Malaria RDT Single Kit (Guatemala). According to the World Malaria Report 2017 [1], in 2016 Honduras, Guatemala and Nicaragua performed 14,930, 74,859 and 880 RDTs, respectively, but only Honduras reported positive results by RDT $(n=241)$. These data represent $8.9,22.4$ and $0.14 \%$ of the total number of diagnostic tests when compared to the microscopic approach. Considering that most of the diagnosis of malaria in these three countries is still carried out through microscopy and the prevalence of $P$. falciparum infections is considerably less than $P$. vivax, the impact of a few false negative results derived from RDTs detecting PfHRP2 would be low for the public health. However, although the risk of diagnostic failures due to non-detection of the parasite by RDT could be low, the countries of the region have proposed eliminating malaria by the year 2030, and this goal requires rapid and timely detection of all cases of malaria, especially in the most remote areas. Consequently, it will be necessary to evaluate the performance of those particular RDTs used in Central America and establish a routine molecular surveillance programme [11].

An interesting result of this study is that most of the isolates (17/27) that did not amplify the intron 1 segment of the pfhrp 2 gene seem to have intact the exon 2 (Table 4). A similar phenomenon occurred for 19 of 27 isolates without the intron 1 of $p f h r p 3$ that successfully amplified the full-length exon 2. A possible explanation for this apparent discrepancy could be the presence of mutations in the primers targets that prevent the amplification of this gene region. However, a more likely hypothesis could be that some parasites suffered breakage points at the end of exon 1 of both genes, as indicated by Cheng et al. [27], which seems to be a relatively common event. With the obtained data it is not possible to assure if the partial or total absence of exon 1 of both genes has consequences for the expression of the PfHRP2 and PfHRP3 antigens, especially because the epitopes relevant for their detection are completely encoded in exon 2 [47] In any case, these results demonstrate the existence of some strains with complete deletions of both genes.

The use of archived samples was a main limitation of the study. Samples were not analysed by serology or RDTs, as recommended by Cheng et al. and supported by the WHO [16, 27, 31]. Therefore, it is not possible to confirm with absolute reliability the diagnostic failure of PfHRP2-based RDTs in Central America. Thus, it will be convenient to carry out further studies comparing the performance of microscopy, RDTs and molecular analysis. As well, sequencing studies of the pfhrp2 gene searching for polymorphisms that could affect the sensitivity of the RDTs are recommended [12, 14, 48, 49].

\section{Conclusions}

In summary, this study provides molecular evidence of the existence of $P$. falciparum isolates lacking the $p f h r p 2$ and $p f h r p 3$ genes, and flanking regions, in Honduras, Guatemala and Nicaragua. This finding could hinder the progress made in the control and elimination of malaria in Central America. From now on, a routine evaluation of the performance of RDTs and molecular surveillance will be required.

\section{Abbreviations \\ pfhrp2 (PfHRP2): Plasmodium falciparum histidine-rich protein 2; pfhrp3 (PfHRP3): Plasmodium falciparum histidine-rich protein 3; WHO: World Health Organization; pfmsp-1: Plasmodium falciparum merozoite surface protein 1; RDT: rapid diagnostic test.}

\section{Authors' contributions}

GF, MPA and REM designed the study. REM and EB collected the samples and identified the parasitic infections through microscopy. LM, IS, GA, BO, AP and GM performed the DNA analyses. GF was a major contributor in writing the manuscript. All authors read and approved the final manuscript.

\section{Author details \\ ${ }^{1}$ Microbiology Research Institute, Universidad Nacional Autonoma de Hondu- ras, Tegucigalpa, Honduras. ${ }^{2}$ Panamerican Health Organization, Tegucigalpa, Honduras. ${ }^{3}$ National Department of Surveillance, Ministry of Health, Teguci- galpa, Honduras. ${ }^{4}$ Panamerican Health Organization, Washington, USA.}

\section{Acknowledgements}

We would like to thank the Sanitary personnel of Guatemala, Nicaragua and Honduras for collecting the samples. The authors thank the Health officials of Guatemala and Nicaragua for providing the blood samples for the study.

\section{Competing interests \\ The authors declare that they have no competing interests.}

Availability of data and materials

The datasets used and/or analysed during the current study are available from the corresponding author on reasonable request.

\section{Consent for publication \\ Not applicable.}

\section{Ethics approval and consent to participate}

The need for ethics approval was waived by the CEI-MEIZ ethics committee of the UNAH because the samples used in this study were obtained from the 
routine diagnosis of malaria carried out by the health ministries of Guatemala, Nicaragua and Honduras. Nevertheless, this study considered all the ethical postulates of the Geneva Declaration.

\section{Funding}

Funding for this study was provided by the Scientific Research Office of the UNAH (DICYP-UNAH), Honduras, and the office of the Pan American Health Organization in Honduras. The funding institutions did not participate in the design of the study and the collection, analysis and interpretation of the data or in the drafting of the manuscript.

\section{Publisher's Note}

Springer Nature remains neutral with regard to jurisdictional claims in published maps and institutional affiliations.

Received: 11 July 2018 Accepted: 27 August 2018

Published online: 31 August 2018

\section{References}

1. WHO. World malaria report 2017. Geneva: World Health Organization; 2017

2. WHO. Global technical strategy for malaria 2016-2030. Geneva: World Health Organization; 2015. p. 29

3. Mouatcho JC, Goldring JP. Malaria rapid diagnostic tests: challenges and prospects. J Med Microbiol. 2013;62:1491-505.

4. Hayward RE, Sullivan DJ, Day KP. Plasmodium falciparum: histidine-rich protein II is expressed during gametocyte development. Exp Parasitol. 2000;96:139-46

5. Wellems TE, Walliker D, Smith CL, do Rosario VE, Maloy WL, Howard RJ, et al. A histidine-rich protein gene marks a linkage group favored strongly in a genetic cross of Plasmodium falciparum. Cell. 1987;49:633-42.

6. Lee N, Baker J, Andrews KT, Gatton ML, Bell D, Cheng Q, et al. Effect of sequence variation in Plasmodium falciparum histidine- rich protein 2 on binding of specific monoclonal antibodies: implications for rapid diagnostic tests for malaria. J Clin Microbiol. 2006;44:2773-8.

7. Gamboa D, Ho MF, Bendezu J, Torres K, Chiodini PL, Barnwell JW, et al. A large proportion of P. falciparum isolates in the Amazon region of Peru lack pfhrp2 and pfhrp3: implications for malaria rapid diagnostic tests. PLOS ONE. 2010;5:e8091.

8. Solano CM, Okoth SA, Abdallah JF, Pava Z, Dorado E, Incardona S, et al. Deletion of Plasmodium falciparum histidine-rich protein 2 (pfhrp2) and histidine-rich protein 3 (pfhrp3) genes in Colombian parasites. PLoS ONE. 2015;10:e0131576.

9. Okoth SA, Abdallah JF, Ceron N, Adhin MR, Chandrabose J, Krishnalall K, et al. Variation in Plasmodium falciparum histidine-rich protein 2 (Pfhrp2) and Plasmodium falciparum histidine-rich protein 3 (Pfhrp3) gene deletions in Guyana and Suriname. PLoS ONE. 2015:10:e0126805.

10. Viana GMR, Okoth SA, Silva-Flannery L, Barbosa DRL, de Oliveira AM, Goldman IF, et al. Histidine-rich protein 2 (pfhrp2) and pfhrp3 gene deletions in Plasmodium falciparum isolates from select sites in Brazil and Bolivia. PLOS ONE. 2017:12:e0171150.

11. Bharti PK, Chandel HS, Ahmad A, Krishna S, Udhayakumar V, Singh N. Prevalence of pfhrp2 and/or pfhrp3 gene deletion in Plasmodium falciparum population in eight highly endemic states in India. PLoS ONE. 2016:11:e0157949.

12. Li P, Xing H, Zhao Z, Yang Z, Cao Y, Li W, et al. Genetic diversity of Plasmodium falciparum histidine-rich protein 2 in the China-Myanmar border area. Acta Trop. 2015;152:26-31.

13. Koita OA, Doumbo OK, Ouattara A, Tall LK, Konare A, Diakite M, et al. False-negative rapid diagnostic tests for malaria and deletion of the histidine-rich repeat region of the hrp2 gene. Am J Trop Med Hyg. 2012:86:194-8.

14. Wurtz N, Fall B, Bui K, Pascual A, Fall M, Camara C, et al. Pfhrp2 and pfhrp3 polymorphisms in Plasmodium falciparum isolates from Dakar, Senegal: impact on rapid malaria diagnostic tests. Malar J. 2013;12:34.

15. Malaria Threats Map. Tracking biological challenges to malaria control and elimination.
16. WHO MPACM. P. falciparum hrp2/3 gene deletions. Conclusions and recommendations of a Technical Consultation. Geneva: World Health Organization; 2016.

17. WHO. False-negative RDT results and implications of new P. falciparum histidine-rich protein 2/3 gene deletions. Geneva: World Health Organization; 2016.

18. Abdallah JF, Okoth SA, Fontecha GA, Torres RE, Banegas El, Matute ML, et al. Prevalence of pfhrp2 and pfhrp3 gene deletions in Puerto Lempira, Honduras. Malar J. 2015:14:19.

19. Fontecha GA, Sanchez AL, Mendoza M, Banegas E, Mejia-Torres RE. A fouryear surveillance program for detection of Plasmodium falciparum chloroquine resistance in Honduras. Mem Inst Oswaldo Cruz. 2014;109:492-3.

20. Torres REM, Banegas El, Mendoza M, Diaz C, Bucheli ST, Fontecha GA, et al Efficacy of chloroquine for the treatment of uncomplicated Plasmodium falciparum malaria in Honduras. Am J Trop Med Hyg. 2013;88:850-4.

21. de Lamballerie X, Zandotti C, Vignoli C, Bollet C, de Micco P. A one-step microbial DNA extraction method using "Chelex 100" suitable for gene amplification. Res Microbiol. 1992;143:785-90.

22. Saiki RK, Scharf S, Faloona F, Mullis KB, Horn GT, Erlich HA, et al. Enzymatic amplification of beta-globin genomic sequences and restriction site analysis for diagnosis of sickle cell anemia. Science. 1985;230:1350-4.

23. Demas A, Oberstaller J, DeBarry J, Lucchi NW, Srinivasamoorthy G, Sumari $D$, et al. Applied genomics: data mining reveals species-specific malaria diagnostic targets more sensitive than 18S rRNA. J Clin Microbiol. 2011;49:2411-8.

24. Fontecha GA, Mendoza M, Banegas E, Poorak M, De Oliveira AM, Mancero T, et al. Comparison of molecular tests for the diagnosis of malaria in Honduras. Malar J. 2012;11:119.

25. Lopez AC, Ortiz A, Coello J, Sosa-Ochoa W, Torres RE, Banegas El, et al. Genetic diversity of Plasmodium vivax and Plasmodium falciparum in Honduras. Malar J. 2012;11:391.

26. Schoepflin S, Valsangiacomo F, Lin E, Kiniboro B, Mueller I, Felger I. Comparison of Plasmodium falciparum allelic frequency distribution in different endemic settings by high-resolution genotyping. Malar J. 2009;8:250.

27. Cheng Q, Gatton ML, Barnwell J, Chiodini P, McCarthy J, Bell D, et al. Plasmodium falciparum parasites lacking histidine-rich protein 2 and 3: a review and recommendations for accurate reporting. Malar J. 2014;13:283.

28. Pava Z, Echeverry DF, Diaz G, Murillo C. Large variation in detection of histidine-rich protein 2 in Plasmodium falciparum isolates from Colombia. Am J Trop Med Hyg. 2010;83:834-7.

29. Dorado EJ, Okoth SA, Montenegro LM, Diaz G, Barnwell JW, Udhayakumar $V$, et al. Genetic characterisation of Plasmodium falciparum isolates with deletion of the pfhrp2 and/or pfhrp3 genes in Colombia: the Amazon region, a challenge for malaria diagnosis and control. PLOS ONE. 2016:11:e0163137.

30. Baldeviano GC, Okoth SA, Arrospide N, Gonzalez RV, Sanchez JF, Macedo $\mathrm{S}$, et al. Molecular epidemiology of Plasmodium falciparum malaria outbreak, Tumbes, Peru, 2010-2012. Emerg Infect Dis. 2015;21:797-803.

31. Kumar N, Pande V, Bhatt RM, Shah NK, Mishra N, Srivastava B, et al. Genetic deletion of HRP2 and HRP3 in Indian Plasmodium falciparum population and false negative malaria rapid diagnostic test. Acta Trop. 2013;125:119-21.

32. Parr JB, Verity R, Doctor SM, Janko M, Carey-Ewend K, Turman BJ, et al. Pfhrp2-deleted Plasmodium falciparum parasites in the Democratic Republic of the Congo: a national cross-sectional survey. J Infect Dis. 2017:216:36-44.

33. Beshir KB, Sepulveda N, Bharmal J, Robinson A, Mwanguzi J, Busula AO, et al. Plasmodium falciparum parasites with histidine-rich protein 2 (pfhrp2) and pfhrp3 gene deletions in two endemic regions of Kenya. Sci Rep. 2017;7:14718.

34. Kozycki CT, Umulisa N, Rulisa S, Mwikarago El, Musabyimana JP, Habimana JP, et al. False-negative malaria rapid diagnostic tests in Rwanda: impact of Plasmodium falciparum isolates lacking hrp2 and declining malaria transmission. Malar J. 2017;16:123.

35. Amoah LE, Abankwa J, Oppong A. Plasmodium falciparum histidine rich protein-2 diversity and the implications for PfHRP 2: based malaria rapid diagnostic tests in Ghana. Malar J. 2016;15:101.

36. Gupta H, Matambisso G, Galatas B, Cistero P, Nhamussua L, Simone W, et al. Molecular surveillance of pfhrp2 and pfhrp3 deletions in Plasmodium falciparum isolates from Mozambique. Malar J. 2017:16:416. 
37. Parr JB, Anderson O, Juliano JJ, Meshnick SR. Streamlined, PCR-based testing for pfhrp2- and pfhrp3-negative Plasmodium falciparum. Malar J. 2018;17:137.

38. Berhane A, Anderson K, Mihreteab S, Gresty K, Rogier E, Mohamed S, et al. Major threat to malaria control programs by Plasmodium falciparum lacking histidine-rich protein 2, Eritrea. Emerg Infect Dis. 2018;24:462-70.

39. Berhane A, Russom M, Bahta I, Hagos F, Ghirmai M, Uqubay S. Rapid diagnostic tests failing to detect Plasmodium falciparum infections in Eritrea: an investigation of reported false negative RDT results. Malar J. 2017; 16:105.

40. Menegon M, L'Episcopia M, Nurahmed AM, Talha AA, Nour BYM, Severini C. Identification of Plasmodium falciparum isolates lacking histidine-rich protein 2 and 3 in Eritrea. Infect Genet Evol. 2017;55:131-4.

41. Su X, Ferdig MT, Huang Y, Huynh CQ, Liu A, You J, et al. A genetic map and recombination parameters of the human malaria parasite Plasmodium falciparum. Science. 1999;286:1351-3.

42. Mapping tool on tracking biological challenges to malaria control and elimination. http://apps.who.int/malaria/maps/threats/. Accessed 25 June 2018.

43. Akinyi S, Hayden T, Gamboa D, Torres K, Bendezu J, Abdallah JF, et al. Multiple genetic origins of histidine-rich protein 2 gene deletion in Plasmodium falciparum parasites from Peru. Sci Rep. 2013;3:2797.
44. Watson OJ, Slater HC, Verity R, Parr JB, Mwandagalirwa MK, Tshefu A, et al. Modelling the drivers of the spread of Plasmodium falciparum hrp2 gene deletions in sub-Saharan Africa. Elife. 2017;6:e25008.

45. Sepúlveda N, Phelan J, Diez-Benavente E, Campino S, Clark TG, Hopkins $\mathrm{H}$, et al. Global analysis of Plasmodium falciparum histidine-rich protein-2 (pfhrp2) and pfhrp3 gene deletions using whole-genome sequencing data and meta-analysis. Infect Genet Evol. 2018:62:211-9.

46. Gatton ML, Dunn J, Chaudhry A, Ciketic S, Cunningham J, Cheng Q. Implications of parasites lacking Plasmodium falciparum histidine-rich protein 2 on malaria morbidity and control when rapid diagnostic tests are used for diagnosis. J Infect Dis. 2017;215:1156-66.

47. Lee N, Gatton ML, Pelecanos A, Bubb M, Gonzalez I, Bell D, et al. Identification of optimal epitopes for Plasmodium falciparum rapid diagnostic tests that target histidine-rich proteins 2 and 3. J Clin Microbiol. 2012;50:1397-405.

48. Deme AB, Park DJ, Bei AK, Sarr O, Badiane AS, Gueye Pel H, et al. Analysis of pfhrp2 genetic diversity in Senegal and implications for use of rapid diagnostic tests. Malar J. 2014;13:34.

49. Atroosh WM, Al-Mekhlafi HM, Al-Jasari A, Sady H, Al-Delaimy AK, Nasr NA, et al. Genetic variation of pfhrp2 in Plasmodium falciparum isolates from Yemen and the performance of HRP2-based malaria rapid diagnostic test. Parasit Vectors. 2015:8:388.
Ready to submit your research? Choose BMC and benefit from:

- fast, convenient online submission

- thorough peer review by experienced researchers in your field

- rapid publication on acceptance

- support for research data, including large and complex data types

- gold Open Access which fosters wider collaboration and increased citations

- maximum visibility for your research: over 100M website views per year

At BMC, research is always in progress.

Learn more biomedcentral.com/submissions 